\title{
FULHAM DOCTORS OF THE PAST *
}

\author{
by
}

\section{A. L. WYMAN}

OrIGINALLY the manor of Fulham comprised both Fulham and Hammersmith but even early in the seventeenth century there was a Fulham side and a Hammersmith side, and the accounts were rendered separately. It was a village near London, situated on the Thames where the river was fordable and the gravelly soil suitable for an early settlement. This was the town where the church was built and the ferry plied to Putney. There were hamlets at Parsons Green and Walham Green and smaller ones at North End and Sands End. It was pleasant enough and convenient enough for London to attract the upper classes. The population was about 730 in the time of Edward VI (1547/8) and over 2,000 towards the end of the seventeenth century. This would be in a population in England of about four million and in London of between 100,000-200,000 (1600). In Roque's map of 1813 we find much the same general pattern. The community was primarily a rural one, with employment on the land as husbandmen, gardeners, labourers, or on the river as fisherman and watermen. As late as 1801 the census shows more people engaged in agricultural pursuits than in trade.

When we come to the doctors it is necessary to make a broad distinction between those who are associated with Fulham because they lived or died there and those who worked there. Some of the former were illustrious but for the most part their main activities were elsewhere and they did not provide any kind of medical service to the local inhabitants, as did the more obscure practitioners who lived and worked in the parish.

The first great name we come across is that of Sir William Butts, Physician to Henry VIII. He was born in Norfolk about the year 1483, and studied at Gonville Hall where he became B.A. in 1506. He was M.D. in 1518. Later he was knighted by the king, the first of the long list of doctors knighted for medical services, symbolizing the rise in status of the profession. In the last few years of his life, some time after 1537, Butts held the lease of the Rectory at Parsons Green and died there in 1545. He was buried in Fulham Church.

His introduction to the Court was probably through his father who was employed as an auditor of Crown revenues in certain large districts of England and later a Custodian of Wards, and also through the patronage of the Duke of Norfolk. He was evidently a successful physician and among his patients were the Queens Anne Boleyn and Jane Seymour, the Princess Mary, Cardinal Wolsey and the Duke of Norfolk. As Physician to Princess Mary he received a livery of blue and green in damask for himself and in cloth for two servants, and cloth for an apothecary. He was not one of the founders of the Royal College of Physicians but although he

* Based on the Presidential Address to the West London Medical Chirurgical Society, 1970. 


\section{Fulham Doctors of the Past}

applied for membership in 1519 he did not become a Fellow until 1529. Although highly esteemed, he did not hold any office in the College. Butts was a supporter of the reformation, a friend of Latimer, Cranmer, and others in high places. When the estates of the Church were confiscated he received grants of abbey lands and other shares of the spoils. Certainly he became very wealthy and beside the house in Fulham he had a house in London and property in Norfolk and Suffolk.

He was not a great innovator in the art or science of medicine but he was one of those doctors who exert much influence in ruling circles, on the whole for good. Such people are not unknown today. It is said that he tried to reconcile Henry VIII and Wolsey. Later he interposed in favour of Archbishop Cranmer. He was a patron of learning and his reputation stood high. Not only do we find him painted by Holbein, but he appears by name in Shakespeare's Henry VIII (1613), being portrayed in a favourable light showing he was well remembered nearly seventy years after his death. Butt's influence, diplomatic skill and medical statesmanship probably had much to do with the formation of the new Barber-Surgeons' Company following the Act of 1540. In the picture by Holbein which was imaginary and symbolical rather than illustrative of any actual event, we see the two royal physicians, John Chambre and Sir William Butts with the King's apothecary on the King's right, while he hands the Act to Thomas Vicary the Serjeant-Surgeon on his left. It is a piece of Tudor propaganda showing the King as the supreme arbiter and bestower of all rights and privileges but it also emphasizes the agreement between the leading physicians and surgeons of the time. His colleagues in the College paid tribute to him, after his death. 'Vir gravis, eximia literarum cognitione, singulare judicid summa experienta, et prudenti consilio, Doctor.' A memorial and brass were put up in Fulham Church, but by 1647 it had fallen into such a bad state that it had to be restored by his grandnephew. Later still the brass disappeared but at least we know what it looked like. The inscription remains.

Another interesting doctor buried in Fulham is Samuel Barrow, M.D. Information about him is scanty and he barely emerges from the shadows, yet he was a man of importance. His connexion with Fulham is that in 1668 he married a widow Lady Dorothy Clarke who lived there and when he died in 1682 it was recorded in the Church Register, 'Samuel Barrow, Esq. one of his Mais Physicians Ord. Sepult 25 March.' From his tombstone we learn that he was fifty-seven years old and so presumably born in 1625, and that he came from Norfolk. He is described as Physician in Ordinary to Charles II and for over twenty years Advocate General and Judge Martial to the English Army, which office he undertook by the King's command, having followed Albemarle, and by his counsels expedited the return of Charles. We can add that he was educated at Trinity College Cambridge and was B.A. in 1643. After the death of Lady Clarke in 1695 an elaborate monument to the couple was erected in the Church.

Lady Clarke's first husband was secretary to Albemarle and as Secretary at War was fatally wounded in a naval engagement with the Dutch in 1666 . Lord Albermarle was originally General George Monk, one of the Parliamentary army commanders and at Cromwell's death, General of the Army in Scotland. He is generally credited with being the leading figure in the negotiations that led to the restoration of Charles II. 


\section{A. L. Wyman}

The parliamentary armies were the first English armies to have a well-organized medical service. Cromwell, like other great generals, was very concerned about the welfare of his men. Further it is probable that there were many more doctors supporting Parliament than the King. That is if we remember that the bulk of the medical services were provided by the Barber-Surgeons and the apothecaries and not by Fellows of the Royal College of Physicians. Each parliamentary army had a Physician-General, paid 10 shillings a day, an Apothecary-General paid $6 s .8 d$. a day and lastly the surgeon paid $4 s .0 d$. a day. Even at the time the payment of the surgeons was regarded as scandalously low.

Samuel Barrow was Physician-General to Monk's Army in Scotland and his career seems to have been closely linked with that of his commander. He was one of Monk's intimates and appears to have been among those responsible for persuading him to march into the City and so pave the way for the restoration. When Monk was appointed Commander in Chief, he promoted those around him and Barrow became Judge Advocate. In 1666 he became Judge Advocate General and was the only doctor ever to hold this important post. We see another side of him a few years later. After the publication of Paradise Lost in 1667, Barrow became an admirer and friend of John Milton as is shown by the commendatory verses in Latin prefixed to the second edition of the poem in 1674 and signed SB. M.D. In the opinion of Milton's biographer (David Masson) the Latin lines attest that Barrow was a scholarly and intelligent man whose admiration was worth something. It is no small thing to recognize greatness at the moment of its appearance and Barrow must be given every credit for his perception. The little we know therefore suggests he was a man of learning and great capacity. Yet he was not a Fellow of the College, nor is there a word about him in the Dictionary of National Biography.

The mention of a few distinguished people does not of course give us much idea of how the community was served. What evidence do we have that ordinary practitioners, barber-surgeons, and apothecaries, were living and working in Fulham in the seventeenth century? They were not ignorant quacks and, as my very distinguished predecessor Dr. W. S. C. Copeman has pointed out in his book-Doctors and Diseases in Tudor Times, they had advanced considerably in prestige and social status by the end of the Tudor period. I have tried to compile a list of medical men who lived, worked or died in Fulham in the seventeenth century. To some degree it may be an overestimate: as we have seen already people like Samuel Barrow were not medically active in the parish. On the other hand there are omissions. Unfortunately for only a few years round the turn of the century do the church registers give the occupation of people entered in them. For example Benjamin Wyche who died in 1686 appears in the register simply as Benjamin Widch buried 15th Sept.-but from the tombstone we find he is a Citizen and Apothecary of London. Unfortunately also, the early church registers have been lost and the record begins only in 1675 .

In 1605 a barber-surgeon named Robert Okeham bought half a cottage at Wandon Greene. Nothing else is known about him. There must however have been a shortage of surgeons in Fulham in the early part of the seventeenth century because in the year 1626 the Overseers of the Poor had to send to Branford (Brentford) to fetch a surgeon, one Richard Nixon, to set 'Widow Colles' legge' for which he was paid 


\section{Fulham Doctors of the Past}

$£ 110$ s. $0 d$. She was still receiving relief during her sickness in the following year so presumably recovery was slow.

During the great outbreak of the plague in 1665 we find frequent reference to one Thomas Gurney who must have been an apothecary called in by the Overseers. We find many entries in the Churchwardens Accounts-such as:

To Tho. Gurney for attending the vissitted people

To Tho. Gurney for attending the sick and vissitted

Tho. Gurney for waiting upon the vissitted

More to Tho. Gurney 10s. Od.

10s. Od.

10s. Od.

10s. Od.

We hear no more of him. It is even possible that he himself became a victim.

For the last quarter of the seventeenth century we can find more evidence of the existence of medical men in Fulham. One of the richest men in the parish was the long-lived Robert Limpany, 1641-1735. Fèret calls him quite flatly a barber-surgeon but does not say on what authority. He was one of a long established Fulham family and was a Liveryman of the Stationers' Company. He probably made most of his money through business and property. He owned a great part of the town of Fulham. If not a barber-surgeon himself, he had some friendly relationship with other barbersurgeons. For example Tho. March had twins who were baptised in Fulham Church in 1700, as 'Limpany and Tomasen, son and dau'. In 1704 he had another son baptised Robert Limpany who died after a few days. Robert Limpany's name was not in the list of Admissions to the Freedom of the Barber-Surgeons' Company but there is an Edward Limpany, son of an Edward Limpany, apprenticed in 1679 and admitted to the Freedom in 1686. This may have been Robert's nephew, the son of his elder brother Edward, who was living in Fulham till 1687. Another connexion with the profession is that in his will dated 1734 Robert left a copyhold to Abraham Odell who was a barber-surgeon working in Fulham at the time.

Other surgeons at this time who appear as parents of children buried in Fulham are John Sparrow, 1699, Charles Goodyear, 1702, John Marbey, 1704; on the Hammersmith side Edward Leynch, 1698, and Peter Crohard, 1701. Apothecaries were fewer but we find Thomas Blencow in 1707 and in Hammersmith Henry Terry, 1699 and Peter Bruchelles, 1700.

Some wealthy apothecaries who died in the parish (from information on their tombstones) were Benjamin Wyche, 'Citizen and Apothecary of London who departed this life the 8 of Sept 1686 aged 55 years' and Samuel Heather 1651-1714 'Operis Pharmaceutici practici Londinensi'. Finally, Bartholomew Shorthose late of the Parish of St. Martin in the Fields died 1727-age undecipherable.

Under the Act of 1512 those who wanted to practise medicine or surgery at this time, if they were not M.D.s of Oxford or Cambridge, had to obtain a licence from the Bishop of the Diocese. In 1676 Thos. Barnaby of Fulham, barber-surgeon, was granted a licence by the Bishop of London. One of those supporting the application was the Reverend Richard Stevenson who had been specially thanked by the Vestry for his efforts in the Great Plague of 1665.

We now come to a physician who practised in Fulham who was rather a cut above the average apothecary. This was Samuel Dwight (1668-1737) the eldest surviving 


\section{A. L. Wyman}

son of John Dwight the famous potter. The pottery can still be seen at the top end of the New King's Road. Apparently their dwelling house was in the High Street. According to Munk's Roll he was a Commoner at Christ Church Oxford in 1687, AB 1691, AM 1693. Dwight seems to have begun his independent career rather late in life. He married in 1718 when he was forty-eight years of age and became a Licentiate of the Royal College of Physicians only in 1731 although he had practised medicine previously. He may have been engaged in the family business and obviously quarrelled with his father who referred to him in his will as his 'undutiful son'.

He wrote three small books: (1) De Vomitione, 1722; (2) De Hydropibus, 1725; (3) De Febribus Symptomaticis, 1731. The last two can be seen in the Library of the Royal College of Physicians. They are written in Latin and in the dedication they are addressed from Fulham. He has attached M.D. to his name with what justification is not known. The last book is dedicated to Sir Hans Sloane whom he often called into consultation and who was at that time President of the Royal College of Physicians. His writings were obviously not world-shaking but he must have been keenly interested in his work.

In the early part of the eighteenth century one of the most important events in the history of Fulham took place: the building of the bridge in 1729. Until then the only bridge across the Thames going back to medieval days was London Bridge. In Cromwell's time, when his headquarters was at Putney, a temporary pontoon bridge connected Fulham and Putney and in the 1670s a Bill to build a permanent bridge was laughed out of Court, but in 1726 a Bill giving permission was successfully passed. In connexion with the building of this bridge we must mention a doctor who, though not an inhabitant of Fulham, firmly left his imprint there: this was the famous William Cheselden (1688-1752) at that time surgeon to St. Thomas's and the new Westminster Infirmary. He made great advances in the treatment of bladder stones and had in 1727, introduced the operation of lateral lithotomy on which his fame rests. He was therefore at that time probably at the peak of his career and energy. Faulkner in his history (1813) practically gives him sole credit as the architect, but it wasn't quite so. It seems that when the trustees of the projected bridge were incorporated, subscriptions were invited and Cheselden put up $£ 1,000$. He became one of the committee of five appointed to consider the designs submitted. The one by

Sir Jacob Ackworth was chosen and the contract given to Mr. Phillips-Chief Carpenter to all his Majesty's Works and Buildings in England, and latterly (1726) Controller of the Board of Works. After that it seems that Cheselden got on to the Building Committee and every committee and sub-committee so that he became the overwhelming influence. He even gave advice and made modifications over Phillip's head, probably altering the original design substantially. His associates at any rate gave him the credit. In 1730 the subscribers and proprietors 'Resolved as the bridge is built entirely according to a scheme and principles laid down by Mr. Cheselden, and as he has been very serviceable in directing the execution of the same, that the thanks of the Proprietors be given to him for the advantages which have been received from his advice and assistance, they being of opinion that no timber bridge can be built in a more substantial and commodious manner than that which is now erected.' Somebody made the jibe that Cheselden was so used to fixing on wooden legs after 
his amputations that this knowledge came in useful in the design of the bridge! He was obviously interested in architecture and took a hand in the original designs of the College of Surgeons after the breakaway from the Barbers in 1745, but he did not complete the task.

We must now consider the organization of the medical services throughout the eighteenth century. The needs of the population had increased by virtue of its natural increase in size. We have guessed that approximately at the end of the seventeenth century the population of Fulham was over 2,000: we know that the estimate in the first census of 1801 was 4,430, of which 511 were engaged in agriculture and only 265 in trade. It was still primarily a rural community. More doctors were available to meet the need and of a higher calibre. The building of the bridge improved communications and led to a greater influx of goods and traffic. There was also an attempt -unsuccessful at first-to improve the roads by means of the various Turnpike Acts. The great problem confronting this and every parish was that of the poor. The Elizabethan Act of 1601 was still in force but it had been modified by the Act of Settlement of 1662 , which had the bad effect of attempting to tackle the problem locally. Paradoxically the interests of the very poor were probably better served under the first two Stuarts when there was an autocratic central government trying to live up to a paternalistic tradition than later when the new forces in society triumphed in the English Revolution. In the parish itself, the authorities could be helpful to those who had a claim on them by right of birth or marriage, but those who came in from outside and could not prove their right were given short shrift and often treated with extraordinary harshness and cruelty. The parish authorities would waste valuable time and money in expensive litigation and other subterfuges to get rid of the (to them) undesirables. 'Not our responsibility, not in our area.' Perhaps such cries are not quite inaudible even now. They seem to awake familiar echoes. At the beginning of the eighteenth century there was general tightening-up of the treatment of the poor and one result was the idea that the problem could be contained and expenditure reduced by forcing all those needing relief to come into workhouses. This was the purport of the Act of 1722 and as a result workhouses were set up in Hammersmith in 1729 and in Fulham in 1732. The parish had to provide some form of medical care for its own poor. This was not laid down explicitly in any act of parliament but it was a matter of practical necessity, of a growing humanitarianism and basically of self-preservation-just as earlier the State had to intervene in the control of the plague. This aspect of medical care did not concern only a small number of people. The standard of living for the majority was so low that at least half the nation was at risk of falling into the clutches of the Poor Law at some time or other. According to one authority the poor-house in old age was the common lot of the industrious agricultural worker who had not improved his position.

There are gaps in the records at the end of the seventeenth century and the beginning of the eighteenth although from the Church registers there is evidence that young active apothecaries and barber-surgeons were living in the parish. In 1713 the Overseers paid 6s. 0d. to Mr. Odel one of the local barber-surgeons 'for curing Dodds boy with a kick of a horse' and we can infer that medical help was brought in as and when required on an ad hoc basis. Sometimes the apothecary is not named but as in 1719 


\section{A. L. Wyman}

it is simply stated that $£ 50$ s. $0 d$. was paid to the apothecary by order, or even, as in 1715 'Paid for several medicines for Mary Job 9s. 6d.' or in the same year 'Paid for Physick and other necesaries for Rochfords family being sick 10s. 6d.' There is a lot of other medical expenditure apart from paying the medical men. The period from 1720 onward marks the great expansion of the voluntary hospital movement and much effort was expended in getting patients into hospital. St. Thomas's was often used and presumably they were sent by boat down river as there are payments for waterage as well as porterage. In 1753 to send a man for the surgeon cost $1 \mathrm{~s}$. $6 \mathrm{~d}$.

In 1729 Dr. Odell was paid $£ 616 s .0 d$. for medicines. There is an increasing tendency to rely on one or two people and in $\mathbf{1 7 3 5}$ there is the significant entry that Mr. Robert Price was paid $£ 53 \mathrm{~s}$. $0 \mathrm{~d}$. 'for attending Jo. Osborne and half a years salary'. In other words now that they had a workhouse functioning, the vestry found it necessary to employ a doctor on a regular basis. The salary was $£ 10$ a year but there were extras, and other people were called in for special cases. The practice had been adopted in other parishes for some time. There is a reference to a salary at St. Austell in Cornwall in 1715. In 1730 the Parish Apothecary at St. Marylebone was paid ten guineas a year. Mr. Robert Price, who died in 1773, seems to have been the mainstay in Fulham from 1734 down to about 1769 . He did not take on the appointment every year: sometimes the work was shared. In $1757 \mathrm{Mr}$. Henry Terry an apothecary of Hammersmith was called in, suggesting that communications between Fulham and Hammersmith had improved. Here are some examples of the kind of work they had to do and the payment received. In $1735 \mathrm{Mr}$. Price was paid $£ 33 \mathrm{~s}$. $0 \mathrm{~d}$. 'for trouble and attending Joseph Osborne for two months, his skull being fractured'. In the same year the vestry agreed to the payment of $£ 212 s$. $6 d$. to Mr. Reed for the cure of Joseph Muggage's child 'who had broke his legg on condition of his giving a Receipt in full for the same'. In 1720 the vestry agreed to $£ 11 \mathrm{~s}$. $0 \mathrm{~d}$. being paid to the surgeon for the cure of Mary Man's daughter; in $1746 \mathrm{Mr}$. Rose, Surgeon, a year's salary $£ 10$ for attending Sick and Curing Broken Bones out of the workhouse $£ 22 \mathrm{~s}$. $0 \mathrm{~d}$. Total $£ 122 \mathrm{~s} .0 \mathrm{~d}$.

The biggest scourge of the eighteenth century was smallpox and there are innumerable references to people being relieved for this. One condition which was rampant in the workhouse especially among children was that of 'scald head'. Presumably this was either an impetigo or ringworm but curiously it was never regarded as coming into the province of the regular doctor and people who claimed special ability to deal with this condition were called in. Esther Wicks in 1757 was paid $f 18 s$. $6 \mathrm{~d}$. for taking care of the children with scald heads. The next year Dr. Duddle (sic) was paid $£ 11$ s. $0 d$. In 1760 James Cook was paid $£ 58 s .0 d$. for the cure of sixteen scald heads in the house, which works out at $6 s .9 d$. a head. Five years later a Mrs. Lanyon was given $10 s$. $6 d$. for the ingredients to cure the children's heads. One gets the impression that certain people wandered from parish to parish claiming to cure this condition. This is not a peculiarity of Fulham. It was a specialist department at St. Bartholomew's as far back as 1534 . Women were generally employed and payment was $3 \mathrm{~s}$. $0 \mathrm{~d}$. a head. At St. Thomas's a specialist surgeon was appointed in 1567 but in 1594 the job was taken on by one of the porters. Paediatrics was a late development and doctors were slow in taking an interest in the problems of children.

In the middle years of the eighteenth century in addition to Mr. Price, Mr. Rose, 


\section{Fulham Doctors of the Past}

Mr. Parry and Mr. Coghlan figure prominently but at the end of the period from $1786 \mathrm{Mr}$. Bunnett was the principal parish doctor.

In the year 1793 an important change was made in the method of appointment of the poor law doctors. Instead of the rather haphazard methods of the past, the vestry decided to follow the example of neighbouring parishes and put out the service to tender. Notices were sent to the different tradesmen and we find the apothecaries in the queue with the butchers, the bakers, the brewers, the coal dealers. The apothecaries were asked to tender 'for medicines and attendances and surgery, for the Poor in the Workhouse, and also such others, as the Officers may think it necessary to assist out of the House'. By an unhappy juxtaposition the carpenters were next on the list after the apothecaries-for coffins, $8 \mathrm{~s}$. $0 \mathrm{~d}$. adults and $4 \mathrm{~s} .0 \mathrm{~d}$. children. These tenders went out every year and the method went on well into the nineteenth century and perhaps in some places even later. It was humiliating to a rising professional class and caused great resentment among doctors which was forcefully expressed in the mid-nineteenth century. Every year Mr. Bunnett was a successful applicant. He obviously had a contact on the committee and he always managed to undercut his rivals. If one applicant offered to do the work for $£ 21$ he offered to do it for $£ 20$. One year he agreed to do it for as little as $£ 10$.

Nevertheless the distress resulting from the Napoleonic wars caused so much increase of work that it became too much for one man. By 1817 the parish was divided into three districts, Mr. Bunnett attending the poor of Fulham Town (including the almhouses and workhouse) and at Crabtree. Mr. Winterbottom attended the poor of Walham Green down to Purser's Cross, North End and Fulham Fields, and Mr. Wansborough, Parsons Green, Sands End and Broomhouse. They were each to be paid $f 20$ a year with extras of 10 s. $6 d$. for each midwifery case outside the house. This kind of arrangement persisted with slight modification and extension right to the end of the Poor Law. The District Medical Officers continued under the London County Council and ceased only in 1948 with the start of the National Health Service.

It might be thought that the importance of these men is exaggerated, that perhaps they were among the least distinguished practitioners in the area. On the contrary they were if anything the leading local medical men. Bunnett, for example, lived in Church Row, the most fashionable part of Fulham, probably in the same house as Robert Limpany, the wealthiest man in Fulham of an earlier generation. Similarly with the others. Why, then, was there competition for these poorly paid posts? The answer is that they were attractive to young men making a start, enabling them to get a foothold in a district with a small amount of assured practice and the possibility of building up a private connexion. The established practitioners wanted the jobs mainly to keep out the young newcomers and stifle competition.

In spite of a certain amount of progress and an increase in population, Fulham was still an attractive place in the mid-eighteenth century and many wealthy and cultivated people lived there. Of course, things are never as good as they were and even in 1705 , Bowack in his Antiquities of Middlesex complains of Fulham town,

it seems at present to be in a declining and languishing condition, not but it boasts of a greater number of houses and inhabitants than was known in it formerly, but the buildings are not so 


\section{A. L. Wyman}

magnificent as those more ancient, nor is there the many honourable and worthy families at present which used to reside upon this spot. It has been much augmented in number of houses of late, for the dwellings of tradesmen, and such as live by their labour, who are chiefly gardners, farmers, husbandmen, and watermen; not that it wants good edifices, and considerable families to enoble it. . . . This place being so conveniently seated, both for passage to London and the pleasure of its walks, is filled during the summer season with abundance of citizens and considerable persons, where, as at its neighbour Putney, and several villages upon the Thames, they are handsomely accommodated with good lodgings to the great advantage of the inhabitants.

One has to think of Fulham then as a bright attractive summer resort, perhaps something like Richmond at the present time. It was a place where people came to retire and where they had their summer residences. And as we shall see, wealthy doctors too succumbed to the lure of Fulham.

The first of these to be mentioned is William Cadogan (1711-1797). It is not certain whether he was born in London or in Cowbridge, Glamorganshire. He went up to Oriel College, Oxford, in 1727 at the age of sixteen as a servitor-which suggests he did not come from the wealthiest of families. After his B.A. in 1731 he went to study medicine at Leyden, then still reflecting the glory of the great Boerhaave who had just retired. He left with an M.D. in 1737. Some time after his return to England he settled in Bristol and married a wealthy girl, and his daughter Frances was born in 1747. In the same year he was elected Physician to the Bristol Royal Infirmary. Cadogan's first claim to fame is an open letter he wrote to one of the Governors of the Foundling Hospital in London (probably by invitation) in 1748. This was published in the same year as An Essay upon Nursing and the Management of Children, from their Birth to Three years of Age, a small book of thirty-four pages. He must have given much thought to the proper management of infants and his thoughts must have been stimulated and crystallised by the practical experience of the care of his daughter. His work was the first scientific exposition on the subject. It blew away the cobwebs of past superstition and mismanagement, of old wives' tales which had been handed down and copied since the time of the Greeks and Romans. To us it seems simple commonsense-matters of feeding, clothing and exercise. At that time the infant mortality was about fifty per cent and even the well-to-do buried most of their large young families. As a result Cadogan became very well known. He was elected a Governor of the Foundling Hospital in 1749 and F.R.S. in 1752. His book was translated into French. In 1752 he resigned from the Bristol Royal Infirmary, bought a house in London, and shortly afterwards was elected Physician to the Foundling Hospital. He was not legally able to practise in the City unless he had a licence from the Royal College of Physicians and to get this he had to be an M.D. of Oxford or Cambridge. He became M.D. of Oxford in 1753 and for good measure he became an M.D. of Cambridge by Royal Mandate. He was elected F.R.C.P. in 1758. Cadogan's other claim to fame is his book $A$ Dissertation on the Gout published in 1771, which created a great stir at the time. Cadogan obviously prospered in London and moved in the best society, numbering many distinguished people among his friends. He lived in George Street, Hanover Square, but in the summer he enjoyed the pleasant atmosphere of Fulham. In 1759 Cadogan, described as a widower, married Ann Spencer, a widow, in All Saints Church, Fulham. He obtained a lease 


\section{Fulham Doctors of the Past}

of three acres from the Bishop of London and the next year 1760 another nine acres, at Hurlingham, site of the old plague pit, and there built his country cottage, his summer residence. His daughter Frances was his constant companion and she was married in Fulham Church in 1780. (Cadogan seems to have been unlucky with his wives because he married for the third time in 1772, a Dutch lady who died in the same year.)

Cadogan himself died in his town house in George Street, but he was buried in Fulham Church. In a recent search his tomb could not be identified, but the inscription has been recorded as follows:

MS./GULIELMI CADOGAN/Oxoniae et Lugduni Batavarum/alumni et M.D./Coll. Reg. Med. Lond./Socii/Ob. XXVI. die. Feb. A.D. MDCCXCVII/aet suae LXXXVI.

[The Church Registers 1797 contain the entry William Cadogan, Esq. Bur. 6 Mar.]

While Cadogan was still living at Hurlingham another medical gentleman high up in the establishment bought a house not far away. This was Sir Francis Milman who came to Fulham in 1791 and stayed until 1804. His house was just to the east of the old Fulham Bridge. It is clearly seen in prints of the time. Milman was born in Devonshire and educated at Exeter College, Oxford. He became an M.B. and an M.D. in 1776 and F.R.C.P. in 1778. Apparently he made the acquaintance of the Duke of Gloucester while in Rome as a Radcliffe travelling fellow and this influence stood him in good stead. In 1778 Milman was Physician Extraordinary to the King's Household and in 1806 became Physician-in-Ordinary to the King: he received a baronetcy.

He appears to have been quite active in the College of Physicians, beginning as a Goulstonian lecturer in 1780, and becoming Croonian lecturer, Harveian orator and five times a censor. He was President for two years, 1811-13, when he resigned, but his term of presidency seems to have been dull and uneventful. Sir George Clark's recent history of the College in two volumes has nothing to say about him beyond giving his name and dates.

He wrote two books, one on dropsy and one on scurvy-of no great merit and no originality. The one on scurvy seems even retrogressive, and does not back up what was already known at the time to Lind and Captain Cook. He gives the impression of a lacklustre and rather negative personality. There is no portrait of him and a few years after he moved from Fulham to Chelsea in 1804, Faulkner (1813) wrote 'The house next to the bridge, late the property of Sir Francis Milman, is now unoccupied and in a ruinous condition.' It was afterwards pulled down. Perhaps his biographer in the Dictionary of National Biography sums him up correctly 'he was a courtly person, of no great medical attainments'.

A more interesting group of people and more closely linked with Fulham are the Sharp family. William Sharp (1729-1810) was the son of Dr. Thomas Sharp, a Prebendary of Durham, and grandson of the Archbishop of York. Apparently he came to London to study surgery at the early age of fourteen, presumably by apprenticeship. This would be about 1743, before the Surgeons had broken away from the Barbers. He set up practice in Old Jewry in the City, and was an assistant Surgeon at St. Bartholomew's Hospital (not to be confused with Samuel Sharp of Guy's). He 


\section{A. L. Wyman}

was appointed to St. Bartholomew's in 1755 and confirmed in the post in 1770, but resigned suddenly and prematurely in 1778 giving a donation of $£ 50$ to the hospital. This entitled him to become a Governor. His excuse was 'engagements in his own private business', but from another source it would appear that the reason was failing eyesight. Two years later, in 1780 , he bought a very fine property at Fulham, just to the west of the bridge, to which he moved with his family, his widowed sister and his famous brother Granville. Granville Sharp will be recalled as one of the first in England to fight for the abolition of slavery. There is a story that in 1765 a brutally treated African slave was brought to St. Bartholomew's by William Sharp and Granville took up his case in the courts, but it was not until 1772 in connexion with another case that Granville was successful in getting the famous judgement of Lord Mansfield that slavery was illegal and whoever stepped on the soil of England was free.

As the family must have overflowed the house, Sharp built a cottage in the grounds right on the waterfront, the two being connected by a subterranean passage.

In 1767 he read a paper to the Royal Society, afterwards published, Account of a New Invented Instrument for Fractured Legs. It must have been well received because in 1788 it was thought worthy of being translated into French together with some writings of Percivall Pott, Sharp's more famous colleague at St. Bartholomew's. He became a Fellow of the Royal Society.

Sharp took a keen interest in parish affairs. Thus we find him in 1790 complaining to the vestry about 'the filthy and disagreeable situation of the Common Sewer' and expressing the opinion 'that the Putrid fevers which have so long existed in the Town and Parish have originated in this nuisance'. Some years later in 1802, he pressed the Workhouse Committee to introduce the 'Innoculation of the Cow-Pox' telling them that it had been proved beyond all possibility of doubt that it was not dangerous in itself and could 'prevent any person who had it from ever after having the Small Pox, which disorder had been lately very prevalent and destructive among the lower classes of People in this Parish and its vicinity'. He therefore asked the committee to consider the best way of introducing the vaccine inoculation among the poor of the parish. This proposal was very sympathetically received and Mr. Bunnett, the workhouse doctor was asked to carry it out. It is evident that Sharp in spite of failing vision and hearing kept up with medical advances, as Jenner's book had been published only four years earlier in 1798.

There is a painting by Zoffany of the Sharp family in their yacht off Fulham holding a musical party. George III and the Queen Caroline were entertained there. One gains the impression that Sharp had a fairly happy retirement and when he died in 1810, at the age of eighty-one, he was buried in All Saints Church just a few yards from his home.

After the Napoleonic wars, the character of Fulham changes rapidly. The population explosion and the improvement in communications, by road and rail, brings us close to the picture of today. The wealthy and the eminent are no longer so much attracted. The big houses could be maintained with difficulty by turning them into private schools or private lunatic asylums. By the end of the century most of them could not survive even on these terms and were bought up and demolished by the 


\section{Fulham Doctors of the Past}

speculative builders who put up dozens of small houses on each site for the skilled working man or the lower middle class.

I have tried to find out what Fulham was like without doctors and without hospitals but it appears that even going back for three or four hundred years, Fulham has not been without its doctors and some sort of medical care provided by the state.

\section{REFERENCES}

Bowack, J., The Antiquities of Middlesex, Part 2, 1705.

Clark, G., A History of the Royal College of Physicians of London, Oxford, Clarendon Press, 1966, vol. 2.

COPE, Z., William Cheselden, Edinburgh, Livingstone, 1953.

Copeman, W. S. C., Doctors and Diseases in Tudor Times, London, Dawsons, 1960.

Dictionary of National Biography.

FAULKNER, T., An Historical and Topographical Account of Fulham, London, 1813.

FèreT, C. J., Fulham Old and New, London, Leadenhall Press, 1900.

FosTER, J., Alumni Oxoniensis, Kraus reprint, Liechtenstein, 1968, vol. 1, p. 436.

Gentleman's Magazine, 1735, 5, 218.

Gentleman's Magazine, 1737, 7, 702.

Gentleman's Magazine, 1810, 80, 396.

GeORGe, D., England in Transition, London, Penguin Books, 1964.

Manners, A. E. D., and Williamson, G. C., Zoffany, London, 1920.

Masson, D., The Life of John Milton, vols. 5 and 6, London, Macmillan, 1880.

McInNes, E. M., St. Thomas' Hospital, London, Allen \& Unwin, 1963.

MOORE, N., History of St. Bartholomew's Hospital, London, Pearson, 1918, vol. 2, pp. 645, 881-82.

MunK, W., The Roll of the Royal College of Physicians, 2nd ed., vol. 1, London, 1878.

OWEN, J., A Discourse occasioned by the Death of William Sharp, Esq., London, 1811.

RENDle-ShORT, J., 'William Cadogan, eighteenth-century physician', Med. Hist., 1960, 4, 288-307.

Rendle-Short, Maud J., The Father of Child Care. Life of William Cadogan 1711-1797, Bristol, Wright, 1966.

Shakespeare, W., Henry VIII, Act 5, Scene ii.

SHEPPARD, F. H. W., Local Government in St. Marylebone, London, Athlone Press, 1950.

TOOMEY, T. N., Ann med. Hist., 1924, 6, 185.

VenN, J. A., Alumni Cantabrigienses, Cambridge, University Press, 1922.

Whitteridge, G. and Stokes, V., A Brief History of the Hospital of Saint Bartholomew, London, The Governors of the Hospital of Saint Bartholomew, 1961.

Manuscript Sources

Barber-Surgeons, Admissions to Freedom 1665-1704, MS. 5265/2. Guildhall Library.

Barber-Surgeons, Register of Apprentices, 1672-1707, MS. 5266/2. Guildhall Library.

Church Register, Fulham, 1675-1735. All Saints Church, Fulham.

Fulham Poor Rate-Overseers accounts and Disbursements. Archives Dept. Hammersmith Library.

Fulham Vestry Minutes. Archives Dept. Hammersmith Library.

ShaRP, W., Typescript, R. Q. 213, 1954. Wellcome Institute of the History of Medicine.

WoodHouse, T. J., Register of Tombs in Fulham Church 1887. All Saints Church, Fulham. 